\title{
Kesiapan Guru Sekolah Dasar dalam Pelaksanaan Pembelajaran \\ Tematik-Integratif pada Kurikulum 2013 \\ di Kota Yogyakarta
}

\author{
Vera Yuli Erviana \\ Elementary Teacher Education Departement, Ahmad Dahlan University \\ vera.erviana@pgsd.uad.ac.id
}

\begin{abstract}
ABSTRAK
Tujuan dari penelitian ini adalah mendeskripsikan kesiapan pelaksanaan pembelajaran tematik-integratif berdasarkan aspek Emotive-Attitudeinal Readiness, Cognitive Readiness, dan Behavioral Readinessbagi bagi guru SD di Kota Yogyakarta terhadap penerapan Kurikulum 2013. Jenis penelitian yang digunakan yaitu penelitian survei. Populasi penelitian adalah guru kelas I dan IV yang terdapat di wilayah Kota Yogyakarta sebanyak 102 guru dengan sampel sebanyak 48 guru SD yang berasal dari 10 SD negeri dan 2 SD swasta yang dijadikan pilot project berdasarkan data dari Kemendikbud DIY.Pendekatan penelitian yang digunakan dalam penelitian ini adalah pendekatan deskriptif kuantitatif.Pengumpulan data dilakukan menggunakan angket kesiapan guru dan didukung dengan wawancara tertutup.Teknik analisis data dilakukan dengan teknik persentase dengan data dibuat secara kategorikal. Hasil penelitan menunjukkan bahwa persentase kesiapan guru SD di Kota Yogyakarta dalam melaksanakan pembelajaran tematik-integratif pada Kurikulum 2013 dilihat dari aspek Emotive-Ettitudinal sebesar 80,75\% (sangat siap), aspek Cognitive Readiness sebesar 73,78\% (siap), dan aspek Behavioral Readiness diperoleh persentase sebesar 84,55\% (sangat siap). Sehingga dapat disimpulkan bahwa guru sekolah dasar di Kota Yogyakarta sudah siap melaksanakan pembelajaran tematik-integratif.
\end{abstract}

Kata Kunci: Kesiapan Guru, Tematik-Integratif, Kurikulum 2013 



\section{Pendahuluan}

Perkembangan ilmu pengetahuan dan teknologi telah membawa perubahan dihampir semua aspek kehidupan manusia dimana berbagai permasalahan hanya dapat dipecahkan dengan upaya penguasaan dan peningkatan ilmu pengetahuan dan teknologi.Selain manfaat bagi kehidupan manusia disatu sisi perubahan tersebut juga telah membawa manusia ke dalam era persaingan global yang semakin ketat.Agar mampu berperan dalam persaingan global, maka sebagai bangsa kita perlu terus mengembangkan dan meningkatkan kualitas sumber daya manusianya.Oleh karena itu, peningkatan kualitas sumber daya manusia merupakan kenyataan yang harus dilakukan secara terencana, terarah, intensif, efektif dan efisien dalam proses pembangunan, kalau tidak ingin bangsa ini kalah bersaing dalam menjalani era globalisasi tersebut.

Irianto, Y.B. (2011: 5), menyatakan bahwa hendaknya pendidikan mampu melahirkan lapisan masyarakat terdidik dan menjadi kekuatan yang merekatkan unitunit sosial di dalam masyarakat. Upaya pembaharuan dan peningkatan kualitas pendidikan pemerintah memastikan diterapkannya kurikulum baru yaitu Kurikulum 2013 yang merupakan penyempurnaan dari kurikulum KTSP yang telah berjalan sebelumnya.Seiring dengan kepastian pemerintah terkait dengan pengembangan kurikulum dari KTSP menuju Kurikulum 2013 memunculkan sebuah tantangan baru bagi guru.Konsep Kurikulum 2013 ini menuntut guru agar menerapkan pembelajaran berbasis tematikintegratif.Pembelajaran tematik bukanlah hal yang baru bagi para guru SD di negara kita ini.Sejatinya model pembelajaran tematik telah diperkenalkan pula pada kurikulum yang sebelumnya yaitu kurikulum KTSP. Pada kurikulum KTSP pembelajaran tematik sudah diterapkan pada kelas I, II, dan III SD. Walau sudah diterapkan di kelas I, II, dan III pada saat kurikulum KTSP berjalan, pelaksanaan pembelajaran tematik dirasa masih sangat kurang efektif.

Perubahan kurikulum KTSP menjadi Kurikulum 2013 telah disiapkan oleh pemerintah.Berbagai upaya telah dilakukan oleh pemerintah sebelum kurikulum yang baru ini benar-benar diterapkan pada tahun ajaran baru 2013.Kegiatan uji publik dilakukan untuk memperoleh masukan dari berbagai lapisan masyarakat.Seminar dan pelatihan-pelatihan bagi guru dalam persiapan menghadapi Kurikulum 2013 ini juga telah dirancang sedemikian rupa.Halhal tersebut dilakukan oleh pemerintah tentunya bertujuan agar ketika Kurikulum 2013 ini dilaksanakan tidak memiliki kendala dan halangan yang berarti bagi para guru sebagai pelaksana di lapangan.

Pengalaman dari kebijakankebijakan sebelumnya mengenai kurikulum 
banyak pihak yang mengeluhkan pergantian kurikulum. Pergantian kurikulum terjadi begitu cepat sehingga membuat para guru kesulitan dalam melaksanakan apa yang dimaksudkan dalam kurikulum tersebut dalam kegiatan di lapangan. Sejatinya perubahan kurikulum memang sudah ditentukan dan disesuaikan dengan tuntutan dan kebutuhan yang ada, namun sosialisasi yang kurang dan persiapan yang kurang matang biasanya menjadi penghambat dan tantangan dalam pelaksanaannya di lapangan.Tidak sedikit pihak-pihak yang menyuarakan bahwa setiap ganti menteri kurikulum ikut berganti.

Sebelum Kurikulum 2013 ini dipastikan diterapkan sudah muncul berbagai isu baik yang pro dan kontra.Argumen-argumen yang bersifat kontra muncul bukan karena tidak punya alasan. Persiapan Kurikulum 2013 yang dinilai terlalu mepet dan tergesa-gesa menjadi sebuah hal yang sering menjadikan keraguan akan keberhasilan pelaksanaan Kurikulum 2013 ini. Seperti yang dinyatakan oleh ketua Persatuan Guru Republik Indonesia (PGRI)Daerah Istimewa Yogyakarta (DIY)Zainal Fanani, menganggap pelaksanaan Kurikulum 2013 terlalu tergesa-gesa. "Pelaksanaan Kurikulum 2013 tergesa-gesa dan dipaksakan pada tahun ajaran baru 2013 ini nanti hasilnya tidak sesuai dengan yang diharapkan dan hanya kulitnya saja”.
Menurut Bandura dkk (Maddox, N. dkk, 2000: 277), menjelaskan kesiapan terdiri dari tiga bagian:1) emotive attitudeinal readiness(kesiapan sikap dan emosi);2) cognitive readiness(kesiapan kognitif), dan 3)behavioral readiness(kesiapan perilaku).Tiga macam kesiapan tersebut menjadi kajian untuk melaksanakan penelitian ini. Kesiapan gurumasih sangat kurang dalam memenuhi setiap kompetensi dalam rangka mencapai tujuan pembelajaran tematik-integratif.

Maka dari itu sosialisasi dan pelatihan Kurikulum 2013 terhadap guruguru sebagai pelaksana di lapangan menjadi sebuah hal yang penting dan wajib hukumnya. Mengingat, guru sebagai motor utama penentu keberhasilan penerapan Kurikulum 2013 ini di lapangan. Kesiapan dan pemahaman guru terhadap ruh Kurikulum 2013 harus dimiliki oleh semua guru. Pemahaman guru terhadap ruh Kurikulum 2013 inilah yang akan menjadikan guru bisa melakukan tindakan yang sesuai dengan maksud dan tujuan yang ada dalam Kurikulum 2013. Dengan demikian kesiapan dan pemahaman guru terhadap Kurikulum 2013 ini menjadi hal yang sangat menentukan dalam keberhasilan dan pencapaian tujuan dari Kurikulum 2013.

Berdasarkan latar belakang masalah yang diuraikan di atas, identifikasi masalah yang diambil yaitu (a) pengembangan 
99 Vera Yuli Erviana, Kesiapan Guru Sekolah Dasar Dalam Pelaksanaan Pembelajaran...

kurikulum dari KTSP menuju Kurikulum 2013 memunculkan tantangan baru bagi guru; (b) pelaksanaan pembelajaran tematik masih kurang efektif; (c) sosialisasi dan persiapan Kurikulum 2013 yang kurang matang membuat guru kesulitan dalam melaksanakan program pemerintah, dan (4) guru belum siap dalam melaksanakan pembelajaran tematik-integratif berdasarkan aspek Emotive-Attitudeinal Readiness, Cognitive Readiness dan Behavioral Readiness.

Berdasarkan identifikasi masalah maka peneliti membatasi penelitian ini tentang kesiapan guru dalam pelaksanaan pembelajaran tematik-integratif berdasarkan aspek Emotive-Attitudeinal Readiness, Cognitive Readiness danBehavioral Readinessdi Kota Yogyakarta terhadap penerapan Kurikulum 2013.

Berdasarkan batasan masalah maka rumusan masalah yang diambil yaitu tentang kesiapan pelaksanaan pembelajaran tematik-integratif berdasarkan aspek Emotive-Attitudeinal Readiness, Cognitive Readiness danBehavioral Readinessbagi guru SD di Kota Yogyakarta terhadap penerapan Kurikulum 2013. Berdasarkan rumusan masalah tersebut, maka tujuan yang ingin dicapai pada penelitian ini adalah mendeskripsikan kesiapan pelaksanaan pembelajaran tematik-integratif berdasarkan aspek Emotive-Attitudeinal Readiness, Cognitive Readiness, dan
Behavioral Readinessbagi guru SD di Kota Yogyakarta terhadap penerapan Kurikulum 2013.

Kesiapan berasal dari kata "siap" mendapat awalan ke- dan akhiran -an. Dalam Kamus Besar Bahasa Indonesia (2003), menjelaskan kesiapan adalah suatu keadaan bersiap-siap untuk mempersiapkan sesuatu. Thorndike (Bower, 2000: 27), menyatakan kesiapan dalam hukum kesiapan (law of readiness) sebagai berikut.

Thordike recognized several forms of readines; if a strong desire for an action sequence is aroused, then the smooth carrying out of that sequence is satisfying; if that action sequence is thwarted or blocked from completion, then such blocking is annoying; if an action is fatigued (tired out) or satiated, then forcing a further repetition of act is annoying.

Artinya bahwa menurut Thorndike ada beberapa kondisi yang akan muncul pada hukum kesiapan ini, diantaranya: (a) jika individu siap untuk bertindak dan mau melakukannya, maka ia akan merasa puas, (b) jika individu siap untuk bertindak, tetapi ia tidak mau melakukannya, maka timbulah rasa ketidakpuasan, (c) jika belum ada kecenderungan bertindak, namun ia dipaksa melakukannya, maka melakukannya akan menjengkelkan, dan (d) jika suatu organisme didukung oleh kesiapan yang kuat untuk memperoleh stimulus maka pelaksanaan tingkah laku akan menimbulkan kepuasan individu sehingga 
asosiasi cenderung diperkuat. Kesiapan akan dapat kita capai apabila ada harapan, dan usaha dalam bentuk perbuatan yang berulang-ulang hingga mencapai tujuan yang diinginkan yaitu berupa kesuksesan.

Menurut Bandura dkk (Maddox, N. dkk, 2000: 277), menjelaskan kesiapan terdiri dari tiga bagian: (a) Emotive Attitudeinal Readiness atau kesiapan sikap dan emosi terdiri dari: (1) kesiapan emosional diasumsikan sebagai tanggung jawab untuk melakukan suatu tugas; (2) antusiasme terhadap suatu tugas, (3) kemauan beradaptasi dengan tugas sewaktuwaktu, (4) kenyamanan dan kemandirian dalam menjalankan tugas, dan (5) mengapresiasi nilai intrinsik dalam suatu tugas, (b) Cognitive Readiness atau kesiapan kognitif terdiri dari: (1) memiliki ketrampilan kognitif dan berpikir kritis yang penting untuk melakukan tugasnya, (2) sadar akan kekuatan dan kekurangan, (3) sudah membuat hubungan antara tugas yang dilakukan dengan kenyataan di lapangan, (4) sadar akan nilai diri dan kemauan untuk menjalankan tugas, dan (5) mampu mengintegrasikan konsep-konsep dan alatalat dari berbagai disiplin keilmuan, (c) Behavioral Readiness atau kesiapan perilaku terdiri dari: (1) bersedia menjalankan fungsi kemitraan dengan rekan-rekan mereka dalam bekerja dan fasilitator, dan (2) mahir mengatur waktu untuk mencapai tujuan yang sesuai dengan
tugasnya.Selain ketiga aspek kesiapan yang telah diuraikan di atas.

Disini juga perlu diperhatikan aspek kesiapan dari segi administratif.Menurut Satori (Danim, 2011: 14), menjelaskan bahwa administrasi merupakan keseluruhan kerjasama dengan memanfaatkan semua sumber personil dan materil yang tersedia dan sesuai untuk mencapai tujuan pendidikan yang telah ditetapkan secara efektif dan efisien. Dalam hal ini kesiapan administrasi dapat dijelaskan sebagai aspek yang mendukung pelaksanaan pembelajaran tematik-integratif dalam Kurikulum 2013. Sesuai dengan Peraturan Menteri Pendidikan Republik Indonesia Nomor 41 Tahun 2007 tentang Standar Proses untuk satuan pendidikan dasar dan menengah menyatakan bahwa standar proses untuk satuan pendidikan dasar dan me $\neg$ nengah mencakup perencanaan proses pembelajaran, pelaksanaan proses pembelajaran, penilaian hasil pem $\neg$ belajaran, dan pengawasan proses pembelajaran. Maka dari itu kesiapan administrasi yang dimaksud di sini adalah kesiapan dukungan material yang dapat membantu mempermudah pelaksanaan pembelajaran tematik-integratif pada Kurikulum 2013 seperti: buku teks, panduan kurikulum, panduan asesmen, dan sebagainya.

Kesiapan guru sangat pentingkarena dalam tujuan Kurikulum 2013, diantaranya 
101 Vera Yuli Erviana, Kesiapan Guru Sekolah Dasar Dalam Pelaksanaan Pembelajaran...

mendorong peserta didik mampu lebih baikdalam melakukan observasi, bertanya, bernalar, dan mengkomunikasikamempresentasikan, apa yang mereka peroleh setelah menerima materi pembelajaran.

Kemdikbud (2013: 9) menjelaskan pembelajaran tematik-integratif merupakan pendekatan pembelajaran yang mengintegrasikan berbagaikompetensi dari berbagai mata pelajaran ke dalam berbagai tema.Pengintegrasian tersebut dilakukan dalam dua hal, yaituintegrasi sikap, keterampilan, dan pengetahuan dalam proses pembelajaran dan integrasi berbagai konsep dasar yang berkaitan.Tema ini menjadi alat pemersatu materi yang beragam dari berbagai mata pelajaran.Pembelajaran tematik dimaknai sebagai pembelajaran yang dirancang dan dikemas berdasarkan tema-tema tertentu dan dalam pembahasannya tema-tema ditinjau dari berbagai mata pelajaran.

Selanjutnya, Trianto (2012: 43) juga mengemukakan bahwa pembelajaran tematik-integratif merupakan tipe pembelajaran tematik yang menggunakan pendekatan antarbidang studi. Model ini dilakukan dengan cara menggabungkan bidang studi dengan menetapkan prioritas kurikuler dan menemukan keterampilan, konsep, dan sikap yang saling tumpang tindih di dalam beberapa bidang studi.
Pembelajaran tematik-integratif memberikan kesempatan kepada peserta didik untuk menghubungkan pengalaman dan pengetahuan sehingga peserta didik lebih mudah menyelesaikan masalah dan memenuhi kebutuhan mereka akan pengetahuan (Huber \& Hutchings, 2008: 1). Pembelajaran tematik-integratif di SD merupakan terapan dari pembelajaran terpadu yaitu mengintegrasikan beberapa aspek baik dalam mata pelajaran maupun antar mata pelajaran dalam sebuah tema. Tema yang dikembangkan dalam pembelajaran tematik-integratif adalah yang berkaitan dengan diri dan lingkungan peserta didik sehingga pembelajaran akan lebih konkret. Pengalaman belajar di sekolah yang relevan dengan kehidupan peserta didik akan membantu peserta didik memecahkan masalah yang dihadapi dalam kehidupan sehari-hari dan dapat memberi pembelajaran bagaimana bersosialisasi dengan masyarakat.

Keterampilan-keterampilan belajar menurut Fogarty (1991: 77) meliputi keterampilan berpikir (tinking skill), ketemapilan sosial (social skill) dan keterampilan mengorganisir (organizing skill).Fogarty (1991: xv) menyebutkan ada 10 model pembelajaran terpadu yang terintegrasi antara lain: 1) fragmented; 2) connected; 3) nested; 4) sequenced; 5) shared; 6) webbed; 7) threaded; 8) integrated; 9) immersed; dan 10) 
networked. Selanjutnya, Fogarty (1991: 76) menambahkan:

The integrated curricular model represents a cross displinary approach similar to the shared model. The integrated model blends the four major disciplines by setting curricular priorities in each and finding the overlapping skills, concepts, and attitude in all four.

Model ini merupakan pembelajaran terpadu yang menggunakan pendekatan antar bidang studi. Model ini diusahakan dengan cara menggabungkan bidang studi dengan cara menetapkan prioritas kurikuler dan menemukan keterampilan, konsep, dan sikap yang saling tumpang tindih di dalam beberapa bidang studi. Pada model ini tema yang berkaitan dan tumpang tindih merupakan hal terakhir yang ingin dicari dan dipilih oleh guru dalam tahap perencanaan program.Pertama kali guru harus menyeleksi konsep-konsep, keterampilan dan sikap yang diajarkan dari beberapa bidang studi, selanjutnya dipilih beberapa konsep, keterampilan dan sikap yang memiliki keterhubungan yang erat dan tumpang tindih di antara berbagai bidang studi.

Guru dalam penerapan pembelajaran tematik-integratif perlu memperhatikan langkah-langkah yang harus dilakukan dalam merancang model pembelajran tematik-integratif. Tujuan dari mengikuti langkah-langkah tersebut adalah agar pembelajaran sudah terkonsep dengan baik dan bisa berjalan dengan lancar.Adapun tahapan-tahapan tersebut menurut Trianto (2010: 64-67) adalah sebagai berikut:a) Tahap Perencanaan,merupakan awal dari proses merancang sebuah model pembelajaran tematik. Pada tahap awal ini mulai terbentuk konsep bagaimana dan apa yang akan dilakukan dalam pembelajaran yang akan dilaksanakan. Pada tahap perencanaan ini meliputi beberapa bagian yaitu 1) Pemilihan Tema, pada dasarnya pemilihan tema merupakan fokus utama dalam pembelajaran tematik. Dimana dari tema tersebut akan mengakomodir materimateri dari berbagai mata pelajaran yang bisa disampaikan dalam satu tema. Adapun beberapa persyaratan yang perlu diperhatikan dalam pemilihan tema pada model pembelajaran tematik (Trianto, 2011: 155) sebagai berikut: (a) tema hendaknya tidak terlalu luas, namun dengan mudah dapat digunakan untuk memadukan banyak mata pelajaran; (b) tema harus bermakna; (c) tema harus disesuaikan dengan tingkat perkembanganpsikologi peserta didik; (d) tema dikembangkan harus mewadahi sebagian besar minat peserta didik; (e) tema yang dipilih hendaknya memperhatikan peristiwa-peristiwa autentik yang terjadi didalam rentang waktu belajar; (f) tema yang dipilih hendaknya memperhatikan kurikulum yang berlaku serta harapan masyarakat (asas relevansi); dan (g) tema 
103 Vera Yuli Erviana, Kesiapan Guru Sekolah Dasar Dalam Pelaksanaan Pembelajaran...

yang dipilih juga hendaknya penulisan yang meliputi: audience,

mempertimbangkan ketersediaan sumber

belajar. 2) Menentukan Jenis Mata

Pelajaran. Karakteristik matapelajaran menjadi hal yang juga penting untuk diperhatikan.Standar kompetensi yang dikembangkan juga harus sesuai dengan tema yang telah dipilih.Menurut Fogarty (199: 28) menyatakan bahwa untuk jenis pembelajaran sosial dan bahasa dapat dipadukan dengan keterampilan berpikir (thinking skill) dengan keterampilan sosial (social skill). 3) Memilih Kajian Materi, Standar Kompetensi, Kompetensi Dasar dan Indikator.Pada langkah ini guru diharapkan mampu menentukan dengan baik sub-sub keterampilan dari masing-masing keterampilan yang dapat diintegerasikan dalam satu tema pembelajaran. 4) Menentukan Sub-Keterampilan yang Dipadukan. Perlu diperhatikan dalam memadukan keterampilan-keterampilan yang akan diintegrasikan dalam satu tema. Secara umum keterampilan yang harus dikuasai meliputi keterampilan berpikir (thinking skill),keterampilan sosial (social skill), dan keterampilan mengorganisasikan (organizer skill).5) Merumuskan Indikator Hasil belajar. Berdasarkan kompetensi dasar dan sub-keterampilan yang dikembangkan maka harus juga dipilih indikator keberhasilan pencapaian dalam pembelajaran. Dimana dalam merumuskan indikator harus berdasarkan kaidah behavior, condition dan degree. 6)

MenentukanLangkah-langkah

Pembelajaran.

Langkah-langkah pembelajaran diperlukan oleh guru untuk mengintegrasikan dan mengorganisasikan pembelajaran agar dapat berjalan secara terstruktur.b) Tahap Pelaksanaan, prinsip utama dalam pelaksanaan pembelajaran terpadu, meliputi: 1) guru hendaknya tidak menjadi single actor yang mendominasi dalam kegiatan pembelajaran. Peran guru sebagai fasilitator dalam pembelajaran memungkinkan peserta didik menjadi pembelajar mandiri; 2) pemberian tanggung jawab individu dan kelompok harus jelas dalam setiap tugas yang menuntut adanya kerja sama kelompok, dan 3) guru perlu akomodatif terhadap ide-ide yang terkadang sama sekali tidak terpikirkan dalam proses perencanaan.c) Tahap Evaluasi, tahap ini harus memperhatikan prinsip evaluasi pembelajaran terpadu antara lain: 1) memberikan kesempatan kepada peserta didik untuk melakukan evaluasi diri di samping bentuk evaluasi lainnya, dan 2) guru perlu mengajak para peserta didik untuk mengevaluasi perolehan belajar yang telah dicapai berdasarkan kriteria keberhasilan pencapaian tujuan yang akan dicapai.

Berdasarkan teori yang dikemukakan sebelumnya, kesiapan dalam penelitian ini terdiri dari tiga aspek antara 
lain: (a) aspek Emotive-Attitudeinal Readinesatau kesiapan sikap dan emosi yang dimaksudkan dalam penelitian ini adalah guru bertanggung jawab dalam proses pembelajaran; guru berkeinginan kuat dalam melaksanakan pembelajaran; guru mampu beradaptasi dengan rekan, tugas, lingkungannya; guru mandiri dalam menjalankan tugas, dan mengapresiasi terhadap penerapan pembelajaran melalui penerapan berbagai sumber belajar dan metode yang sesuai dengan Kurikulum 2013, (b) aspek Cognitive Readiness atau kesiapan kognitif yang dimaksudkan dalam penelitian ini adalah guru berpikir kritis yang ditunjukkan mampu membuat peserta didik aktif, kreatif dalam mengembangkan ide, sesuai dengan tingkat kecerdasan dan penalaran peserta didik; guru sadar akan kelebihan dan kekurangan Kurikulum 2013; guru menilai bahwa pembelajaran relevan dengan kondisi di lapangan; guru memiliki kemauan yang ditunjukkan melalui kesadaran diri akan ketidakpahaman Kurikulum 2013; dan guru mampu menggabungkan konsep-konsep dan alatalat dari berbagai mata pelajaran, dan (c) Aspek Behavioral Readiness atau kesiapan perilaku yang dimaksudkan dalam penelitian ini adalah guru bersedia menjalankan fungsi kemitraan dengan rekan kerja, dan guru mampu mengatur waktu dalam mencapai tujuan yang sesuai dengan tugas.
Berdasarkan uraian di atas, maka pertanyaan penelitiannya adalah (a) bagaimana kesiapan pelaksanaan pembelajaran tematik-integratif berdasarkan aspek Emotive-Attitudeinal Readiness bagi guru SD di Kota Yogyakarta terhadap penerapan Kurikulum 2013?; (b) bagaimana kesiapan pelaksanaan pembelajaran tematik-integratif berdasarkan aspek Cognitive Readiness bagi guru SD di Kota Yogyakarta terhadap penerapan Kurikulum 2013, dan (c) bagaimana kesiapan pelaksanaan pembelajaran tematik-integratif berdasarkan aspek Behavioral Readinessbagi guru SD di Kota Yogyakarta terhadap penerapan Kurikulum 2013?

\section{Metode Penelitian}

Penelitian ini termasuk jenis penelitian survei yang bertujuan untuk mengetahui kesiapan guru sekolah dasar dalam pelaksanaan pembelajaran tematikintegratif pada Kurikulum 2013.Informasi yang terkumpul dapat dijadikan sebagai dasar atau landasan untuk membuat rekomendasi dalam mendukung kebijakan atau keputusan tentang pelaksanaan pembelajaran tematik-integratif.

Penelitian survei ini mengacu pada langkah-langkah penelitian survei yang dikemukakan Rea dan Parker(Sukmadinata, N.S. 2010: 90) sebagai berikut: (1) identification of the focus of the study and method of research; (2) the research 
105 Vera Yuli Erviana, Kesiapan Guru Sekolah Dasar Dalam Pelaksanaan Pembelajaran...

schedule and budget;(3) establishment of an information based; (4) the sampling frame; (5) determination of sample size and sampel selection; (6) design of the survey instrument; (7) pretest of survey instrument; (8) selection and training intervie; (9) implementation of the survey,; (10) codification of the completed questionnaires and computerized data entry, and (11) data analiysis and final report.

Rencana penelitian mulai dari identification of the focus of the study and method of research pada tahap ini peneliti mengidentifikasi fokus dan metode yang akan digunakan dalam penelitian, pada tahap kedua the research schedule and budget yaitu membuat jadwal penelitan dan anggaran penelitian, pada tahap tiga establishment of an information basedpada tahap ini peneliti membangun informasi dasar, tahap empat the sampling framepada tahap ini peneliti menentukan sampel, tahap lima determination of sample size and sampel selection pada tahap ini peneliti menjelaskan ukuran sampel dan cara memilih sampel, tahap keenam design of the survey instrumentpada tahap ini peneliti membuat instrumen survei, tahap ke tujuh pretest of survey instrumentpada tahap ini peneliti melakukan uji coba terhadap instrumen, tahap kedelapan selection and training interviewpada tahap ini memilih dan berlatih untuk mewawancarai, tahap ke sembilan implementation of the surveypada tahap ini peneliti melaksanakan penelitian survei, tahap kesepuluh codification of the completed questionnaires and computerized data entry pada tahap ini peneliti melakukan penandaan dan melengkapi angket serta memasukkan data pada komputer,dan terakhir adalah data analiysis and final report pada tahap terakhir ini peneliti menganilisis dan melaporkan.

Penelitian ini akan dilaksanakan di

SD wilayah Kota Yogyakarta.Pada penelitian ini, yang menjadi populasi adalah guru SD di Kota Yogyakarta.Teknik sampling yang digunakan dalam penelitian ini adalah menggunakan purposive sampling dimana subjek ditentukan oleh peneliti. Penentuan sampel yang dijadikan responden dalam penelitian ini menggunakan tabel Krejcie and Morgan.Untuk lebih jelasnya dapat dilihat pada Tabel 1 di bawah ini.

Tabel 1.Jumlah Populasi dan Sampel SD di Kota Yogyakarta

\begin{tabular}{|c|c|}
\hline Populasi Guru SD & Sampel Guru SD \\
\hline 102 & 48 \\
\hline
\end{tabular}
digunakan dalam penelitian ini adalah angket yang berupa angket tertutup dan angket terbuka.Dari hasil angket yang diperoleh akan dilakukan skoring dengan rentang 1-4.Instrumen pengumpulan data dalam penelitian ini adalah lembar angket dan pedoman wawancara.Angket ini digunakan untuk mengumpulkan data 
kesiapan guru dalam pelaksanaan

pembelajaran tematik-integratif pada

Kurikulum 2013.

Tabel 2.Kisi-KisiAngket Tertutup Kesiapan Guru Sekolah Dasar

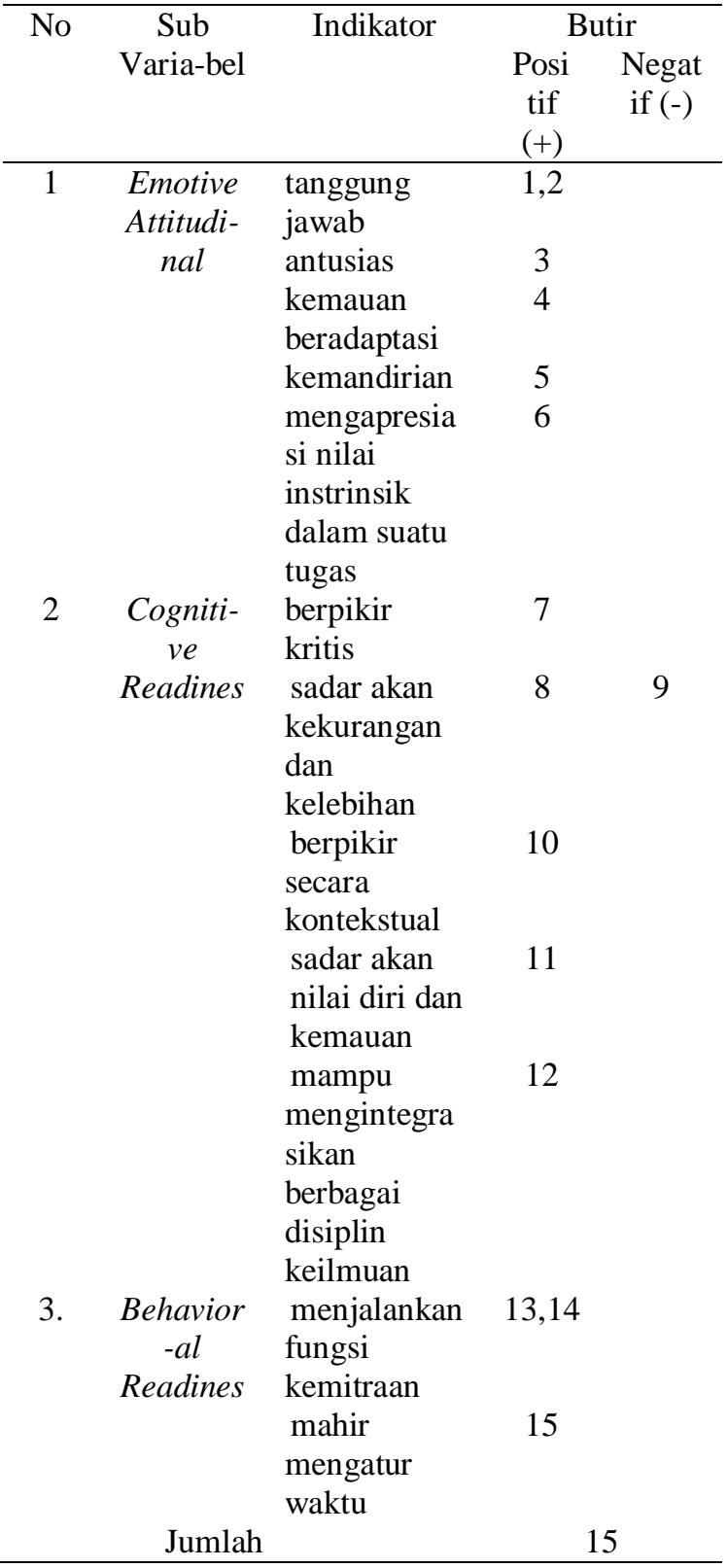

Berikut ini adalah kisi-kisi angket terbuka kesiapan guru dalam melaksanakan pembelajaran tematik-integratif sesuai Kurikulum 2013.

Tabel 2.Kisi-KisiAngket Terbuka Kesiapan Guru Sekolah Dasar

\begin{tabular}{|c|c|c|c|c|}
\hline No & $\begin{array}{c}\text { Sub } \\
\text { Varia-bel }\end{array}$ & Indikator & $\begin{array}{l}\text { Nom } \\
\text { or } \\
\text { Butir }\end{array}$ & $\begin{array}{c}\text { Jumla } \\
\mathrm{h} \\
\text { butir }\end{array}$ \\
\hline \multirow[t]{6}{*}{1} & Emotive & tanggung & 1 & 1 \\
\hline & Attitudi- & jawab & & \\
\hline & & antusias & 2,3 & 2 \\
\hline & & $\begin{array}{l}\text { kemauan } \\
\text { beradaptasi }\end{array}$ & 4 & 1 \\
\hline & & kemandirian & 5 & 1 \\
\hline & & $\begin{array}{l}\text { mengapresia } \\
\text { si nilai } \\
\text { instrinsik } \\
\text { dalam suatu } \\
\text { tugas }\end{array}$ & 6 & 1 \\
\hline \multirow[t]{5}{*}{2} & $\begin{array}{c}\text { Cogniti- } \\
\text { ve }\end{array}$ & $\begin{array}{l}\text { berpikir } \\
\text { kritis }\end{array}$ & 7 & 1 \\
\hline & Readines & $\begin{array}{l}\text { sadar akan } \\
\text { kekurangan } \\
\text { dan } \\
\text { kelebihan }\end{array}$ & 8 & 1 \\
\hline & & $\begin{array}{l}\text { berpikir } \\
\text { secara } \\
\text { kontekstual }\end{array}$ & 9 & 1 \\
\hline & & $\begin{array}{l}\text { sadar akan } \\
\text { nilai diri dan } \\
\text { kemauan }\end{array}$ & 10 & 1 \\
\hline & & $\begin{array}{l}\text { mampu } \\
\text { mengintegra } \\
\text { sikan } \\
\text { berbagai } \\
\text { disiplin } \\
\text { keilmuan }\end{array}$ & 11 & 1 \\
\hline \multirow[t]{3}{*}{3.} & $\begin{array}{c}\text { Behavior } \\
- \text {-al }\end{array}$ & $\begin{array}{l}\text { menjalankan } \\
\text { fungsi }\end{array}$ & 12 & 1 \\
\hline & Readines & $\begin{array}{l}\text { kemitraan } \\
\text { mahir } \\
\text { mengatur } \\
\text { waktu }\end{array}$ & 13 & 1 \\
\hline & Jumlah & & \multicolumn{2}{|c|}{13} \\
\hline
\end{tabular}

Teknik analisis data yang digunakan dalam penelitian ini adalah menggunakan teknik presentase. Purwanto (2008:219) menyatakan bahwa presentase nilai jawaban responden didapat melalui Rumus: 
107 Vera Yuli Erviana, Kesiapan Guru Sekolah Dasar Dalam Pelaksanaan Pembelajaran...

$$
\frac{\text { Nilai Skor Harapan }}{\text { Nilai Harapan }} \times 100 \%
$$

Hasil presentase, kemudian dikategorikan menjadi empat kategori sebagai berikut.

Tabel 3. Interpretasi Secara Kualitatif dari Persentase

\begin{tabular}{cl}
\hline Persentase & \multicolumn{1}{c}{ Kategori } \\
\hline $76 \%<x \leq 100 \%$ & Sangat siap \\
$51 \%<x \leq 76 \%$ & Siap \\
$26 \%<x \leq 51 \%$ & Kurang Siap \\
$0 \% \leq x \leq 26 \%$ & Tidak siap \\
\hline
\end{tabular}

\section{Hasil Penelitian}

Hasil penelitian tentang kesiapan pelaksanaan pembelajaran tematik-integratif berdasarkan aspek Emotive-Attitudeinal Readiness, Cognitive Readiness, danBehavioral Readiness bagi guru SD di Kota Yogyakarta terhadap penerapan Kurikulum 2013. Berikut adalah hasil presentase kesiapan Emotive-Attitudinal di Kota Yogyakarta:

Tabel 2. Persentase Emotive-Attitudinal di

\begin{tabular}{|c|c|c|c|}
\hline \multicolumn{4}{|c|}{ Kota Yogyakarta } \\
\hline Kriteria & $\begin{array}{c}\text { Nilai } \\
\text { Skor } \\
\text { Jawaban }\end{array}$ & $\begin{array}{c}\text { Prosentase } \\
(\%)\end{array}$ & $\begin{array}{c}\text { Kategor } \\
\text { i }\end{array}$ \\
\hline Tanggung & & & Sangat \\
\hline Jawab & 305 & 79,43 & $\begin{array}{c}\text { siap } \\
\text { Sangat }\end{array}$ \\
\hline Antusias & 146 & 76,042 & siap \\
\hline Kemauan & & & Sangat \\
\hline Beradaptasi & 157 & 81,77 & $\begin{array}{c}\text { siap } \\
\text { Sangat }\end{array}$ \\
\hline $\begin{array}{l}\text { Kemandirian } \\
\text { Mengapresias }\end{array}$ & 160 & 83,33 & siap \\
\hline i Nilai & & & Sangat \\
\hline Intrinsik & 162 & 84,375 & $\begin{array}{c}\text { siap } \\
\text { Sangat }\end{array}$ \\
\hline Total & 930 & 80,73 & siap \\
\hline
\end{tabular}

Berdasarkan Tabel 2 diperoleh hasil presentase Emotive-Attitudinal untuk Kota Yogyakarta adalah sebesar $80,73 \%$, yang meliputi presentase tanggung jawab sebesar $79,43 \%$, presentase antusias sebesar $76,04 \%$, presentase kemauan beradaptasi sebesar $81,77 \%$, presentase kemadirian sebesar 83,33\%, dan presentase mengapresiasi nilai intrinsik sebesar $84,38 \%$. Sedangkan untuk hasil angket terbuka pada aspek Emotive-Attitudinal sudah dikatakan sangat siap hal ini ditunjukkan dengan guru selalu berusaha mencari informasi pelaksanaan pembelajaran tematik-integratif, melaksanakan pembelajaran yang mengacu pada tema yang ada, menggunakan metode pembelajaran yang bervariasi, dan menggunakan sumber belajar yang dekat dengan siswa.

Berdasarkan hasil angket terbuka tentang kesiapan guru dari sisi emotiveattitudinal di Kota Yogyakarta yang terdiri dari tanggung jawab, antusias, kemauan beradaptasi, kemandirian, mengapresiasi nilai instrinsik dalam suatu tugas menunjukan bahwa guru siap. Tanggung jawab ditunjukan dengan guru sudah melaksanakan kurikulum 2013 dengan beberapa kekurangan. Antusiasme guru ditunjukan dengan guru selalu mencari informasi mengenai pelaksanaan pembelajaran dengan cara mengikuti sosialisasi, pelatihan, diklat, dan membaca 
buku pegangan. Kemauan beradaptasi ditunjukan dengan melaksanakan pembelajaran yang berpedoman pada buku yang berikan pemerintah, mencari informasi terkait dari berbagai media, menyesuaikan petunjuk buku yang yang diberikan ketika diklat, melaksanakan pembelajaran sesuai dengan pelatihan yang diterima.Kemandirian ditunjukan melalui pelaksanaan pembelajaran secara mandiri tanpa didampingi, melakukan diskusi, kerja kelompok dengan rekan sejawat.Mengapresiasi nilai instrinsik dalam suatu tugas melalui penerapan berbagai sumber belajar dan metode yang sesuai dengan kurikulum 2013.

Berikut adalah hasil presentase kesiapan Cognitive Readiness di Kota Yogyakarta:

Tabel 3. Persentase Cognitive Readiness di Kota Yogyakarta

\begin{tabular}{|c|c|c|c|}
\hline Kriteria & $\begin{array}{l}\text { Nilai } \\
\text { Skor } \\
\text { Jawa } \\
\text { ban }\end{array}$ & $\begin{array}{c}\text { Prosentase } \\
(\%)\end{array}$ & Kategori \\
\hline $\begin{array}{l}\text { Berpikir } \\
\text { Kritis }\end{array}$ & 149 & 77,604 & Sangat siap \\
\hline $\begin{array}{l}\text { Sadar akan } \\
\text { kekurangan } \\
\text { \& kelebihan }\end{array}$ & 237 & 61,72 & Siap \\
\hline $\begin{array}{l}\text { Berpikir } \\
\text { secara } \\
\text { kontekstual }\end{array}$ & 144 & 75 & Siap \\
\hline $\begin{array}{l}\text { Sadar akan } \\
\text { nilai diri dan } \\
\text { kemauan }\end{array}$ & 178 & 92,71 & Sangat siap \\
\hline $\begin{array}{l}\text { Mampu } \\
\text { mengintegra } \\
\text { sikan } \\
\text { berbagai } \\
\text { disiplin ilmu }\end{array}$ & 142 & 73,96 & Siap \\
\hline Total & 850 & 73,78 & Siap \\
\hline
\end{tabular}

presentase Cognitive Readiness untuk Kota Yogyakartaadalah sebesar $73,78 \%$, yang meliputi presentase berpikir kritis sebesar $77,6 \%$, presentase sadar akan kekurangan dan kelebihan sebesar $61,72 \%$, presentase berpikir secara kontekstual sebesar $75 \%$, presentase sadar akan nilai diri dan kemauan sebesar 92,71\%, dan presentase mampu mengintegrasikan berbagai disiplin ilmu sebesar 73,96\%. Sedangkan untuk hasil angket terbuka pada aspek Cognitive Readinesssudah dikatakan siap hal ini dapat dilihat dari pernyataan guru, bahwa kurikulum 2013 sudah sesuai untuk meningkatkan kemampuan peserta didik tetapi masih perlu penyempurnaan,dapat menganalisis kelebihan dan kekurangan pembelajaran tematik-integratif, pembelajaran tematik-integratif sesuai dengan kondisi sosial, budaya, dan lingkungan sekitar, memahami kekurangan dan kelebihan diri dalam mengimplementasikan kurikulum 2013, dan memilih metode yang disesuai dengan tema.

Kesiapan guru dari sisi cognitive readiness di Kota Yogyakarta yang terdiri dari berpikir kritis, sadar akan kekurangan dan kelebihan, berfikir secara kontekstual, sadar akan nilai diri dan kemauan, mampu mengintegrasikan berbagai disiplin keilmuan menunjukan bahwa guru siap. Berpikir kritis ditunjukan melalui penilaian guru bahwa pembelajaran tematik-integratif 
109 Vera Yuli Erviana, Kesiapan Guru Sekolah Dasar Dalam Pelaksanaan Pembelajaran...

sudah tepat untuk anak sekolah dasar karena pembelajaran tersebut membuat peserta didik aktif, kreatif mengembangkan ide, sesuai dengan tingkat kecerdasan dan penalaran peserta didik, dan melalui pembelajaran dapat menerapkan nilai-nilai atau sifat-sifat ilmiah (mengamati, menanya, menalar, mencoba, mengolah, menyajikan, menyimpulkan, dan mengomunikasikan). Guru sadar akan kekurangan kurikulum 2013 ditunjukan dengan merasa lemah apabila mata pelajaran Pendidikan Jasmani, Olahraga, dan Kesehatan diampu oleh guru bidang studi, guru belum menguasai tetapi harus menyampaikan dan menerapkan kepada peserta didik, anak-anak yang kurang mampu akan tertinggal dengan teman, waktu pembelajaran terbatas guru kesulitan menyelesaikan materi sesuai jadwal. Guru sadar akan kelebihan kurikulum 2013 ditunjukan dengan pendapat guru bahwa pembelajaran lebih bermakna, mengaktifkan siswa, siswa mampu berpikir sendiri sesuai pengalaman, materi mudah dipahami peserta didik dan prospek jangka panjang karakter peserta didik lebih terbentuk. Berpikir secara kontekstual ditunjukan dengan pelaksanaan pembelajaran disesuaikan dengan lingkungan, budaya, sosial disekitar agar pembelajaran bermakna dan berhasil. Sadar akan nilai diri dan kemauan ditunjukan melalui kesadaran diri akan ketidakpahaman terhadap kurikulum
2013, berusaha menguasai dan mengimplementasikan kurikulum 2013, dan guru harus melakukan simulasi percobaan terlebih dahulu sebelum mengajar. Mampu mengintegrasikan berbagai disiplin keilmuan ditunjukan melalui kemampuan guru dalam mengintegrasikan muatan mata pelajaran, dan menyajikan pembelajaran melalui pendekatan scientific.

Berikut adalah hasil presentase kesiapan Behavioral Readiness di Kota Yogyakarta:

Tabel 4. Persentase Behavioral Readiness di Kota

\begin{tabular}{lccc}
\multicolumn{4}{c}{ Yogyakarta } \\
\hline \multicolumn{1}{c}{ Kriteria } & $\begin{array}{c}\text { Nilai } \\
\text { Skor } \\
\text { Jawaban }\end{array}$ & $\begin{array}{c}\text { Prosent } \\
\text { ase (\%) }\end{array}$ & Kategori \\
\hline $\begin{array}{l}\text { Menjalankan } \\
\text { fungsi } \\
\text { kemitraan } \\
\begin{array}{l}\text { Mahir } \\
\text { mengatur } \\
\text { waktu }\end{array}\end{array}$ & 328 & 85,42 & $\begin{array}{c}\text { Sangat } \\
\text { siap }\end{array}$ \\
\multicolumn{1}{c}{ Total } & 159 & 82,813 & $\begin{array}{c}\text { Sangat } \\
\text { siap } \\
\text { Sangat } \\
\text { siap }\end{array}$ \\
\hline
\end{tabular}

Berdasarkan Tabel 4 diperoleh hasil presentaseBehavioral Readiness untuk Kota Yogyakarta adalah sebesar $84,55 \%$, yang meliputi presentase menjalankan fungsi kemitraan sebesar $85,42 \%$, dan presentase mahir mengatur waktu sebesar $82,81 \%$. Sedangkan untuk hasil angket terbuka pada aspek Behavioral Readinessdikatakan sangat siap hal ini ditunjukkan dengan guru melakukan diskusi dengan teman sejawat tentang kendala yang dihadapi dalam melaksanakan kurikulum 2013 agar tujuan pembelajaran dapat tercapai secara optimal dan memanfaatkan waktu pembelajaran 
sebaik mungkin setiap melaksanakan kegiatan pembelajaran.

Kesiapan guru dari sisi behavioral readinessdi Kota Yogyakarta yangterdiri dari kesiapan menjalankan fungsi kemitraan dan mahir mengatur waktu.Kesiapan menjalankan kemitraan ditunjukan dengan dengan melakukan koordinasi, sharing, dan diskusi mengenai kegiatan belajar mengajar, materi, dan persepsi. Mahir mengatur waktu ditunjukan dengan menyesuaikan jumlah jam pada struktur kurikulum 2013 pada setiap muatan.

Berdasarkan hasil penelitian yang telah dikemukakan, berikut dipaparkan beberapa temuan dalam pelaksanaan penelitian ini. Persentase kesiapan guru sekolah dasar dalam pelaksanaan pembelajaran tematikintegratif pada Kurikulum 2013 dilihat dari ketiga aspek yang menjadi perhatian peniliti, aspek Behavioral Readiness merupakan aspek yang memiliki persentase terbesar yaitu 84,55\%, sedang aspek Emotive-Ettitudinal sebesar $80,73 \%$ dan aspek Cognitive Readiness sebesar 73,78\%. Artinya, dari aspek Behavioral Readiness dan Emotive-Ettitudinal kesiapan guru dalam melaksanakan pembelajaran tematikintegratif termasuk kategori sangat siap, sedangkan dari aspek Cognitive Readiness termasuk kategori siap.

Persentase dari aspek EmotiveEttitudinal di Kota Yogyakarta yaitu $80,73 \%$. Tingginya persentase pada Kota
Yogyakarta pada aspek tersebut dikarenakan adanya tanggungjawab, antusiasme, kemauan beradaptasi dan kemandirian yang tinggi pada guru-guru dan sekolah dasar selain itu didukung dengan adanya sarana dan prasarana yang memadai. Persentase dari aspek Cognitive Readiness di Kota Yogyakarta sebesar 73,78\%. Kemampuan dan pemahaman guru dalam pembelajaran tematik-integratif, sadar akan nilai diri dan kemauan, kemampuan mengintegrasikan berbagai disiplin ilmu dan pola pikir kontekstual yang tinggi menjadikan guru-guru sekolah dasar di Kota Yogyakarta siap untuk melaksanakan pembelajaran tematik-integratif sehingga persentase yang diperoleh juga terbesar. Pada aspek Behavioral Readiness perolehan persentase di Kota Yogyakarta yaitu sebesar 84,55. Tingginya persentase Kota Yogyakarta pada aspek Behavioral Readiness dikarenakan berjalannya fungsi kemitraan dengan baik pada sekolah maupun guru, yaitu antar guru selalu melakukan evaluasi terhadap proses pembelajaran yang telah dilaksanakan, melakukan diskusi antar guru, melakukan refleksi dan keteraturan dalam mengatur waktu yang tersedia.

Kesiapan guru dalam melaksanakan kurikulum 2013 juga didukung dari hasil angket terbuka yang diberikan pada guru dari segi kesiapan Emotive-Ettitudinal, Cognitive Readiness danBehavioral 
111 Vera Yuli Erviana, Kesiapan Guru Sekolah Dasar Dalam Pelaksanaan Pembelajaran...

Readiness. Hasil dari segi kesiapan

Emotive-Ettitudinal adalah (1) guru bertanggung jawab dalam melaksanakan kurikulum 2013; (2) antusiasme mencari informasi mengenai pelaksanaan pembelajaran dengan cara mengikuti sosialisasi, pelatihan, diklat, dan membaca buku pegangan; (3) mau beradaptasi dengan kurikulum 2013; (4) berusaha mandiri, dan (5) mengapresiasi nilai instrinsik dalam suatu tugas melalui penerapan berbagai sumber belajar dan metode yang sesuai dengan kurikulum 2013.

Hasil analisis angket terbuka dari segi kesiapan Cognitive Readiness adalah (1) guru menilai bahwa pembelajaran tematikintegratif sudah tepat untuk anak sekolah dasar; (2) guru sadar akan kekurangan kurikulum 2013; (3) guru sadar akan kelebihan kurikulum 2013; (4) pelaksanaan pembelajaran sudah disesuaikan dengan lingkungan, budaya, sosial sekitar; (5) sadar akan nilai diri dan kemauan ditunjukan melalui kesadaran diri akan ketidakpahaman terhadap kurikulum 2013, dan (6) mampu mengintegrasikan berbagai disiplin keilmuan.

Hasil analisis angket terbuka dari segi kesiapan Behavioral Readiness adalah (1) kesiapan menjalankan kemitraan dengan teman sejawat dan (2) mahir mengatur waktu dalam melaksanakan kurikulum 2013.
Hoover (1990) menyatakan bahwa ada lima tahap dalam mengimplementasikan kurikulum yaitu: menentukan kebutuhan untuk adaptasi kurikulum, mengidentifikasi elemen-elemen yang diminta dalam beradaptasi, memilih teknik mengajar dan manajemen perilaku, mengimplementasikan kurikulum, dan memonitor perkembangan adaptasi yang dilakukan. Berdasarkan hasil penelitian yang diperoleh tentang kesiapan guru dalam menerapkan kurikulum 2013, guru sudah melaksanakan beberapa tahap dalam mengimplementasikan kurikulum menurut Hoover. Tahap-tahap yang sudah dilaksanakan guru adalah menentukan kebutuhan untuk adaptasi kurikulum, mengidentifikasi elemen-elemen yang diminta dalam beradaptasi, memilih teknik mengajar dan manajemen perilaku. Hal ini ditunjukan dengan kesiapan emotiveettitudinal yaitu pada aspek kemauan beradaptasi. Berdasarkan hasil penelitian di atas aspek kemauan beradaptasi dinyatakan sangat siap dengan persentase sebesar $79,05 \%$.

Keterbatasan penelitian ini hanya memaknai kesiapan guru terhadap Kurikulum 2013 dari aspek EmotiveAttitudinal, Cognitive Readiness, dan Behavioral Readiness. Penelitian ini belum mendalam sampai segi pembuatan perangkat pembelajaran, diantaranya: pembuatan RPP, pembuatan media, pembuatan materi ajar, dan pembuatan alat 
evaluasi yang sesuai dengan Kurikulum 2013.

\section{Simpulan}

Berdasarkan hasil penelitian yang dilakukan di Provinsi Daerah Istimewa Yogyakarta tentang kesiapan guru sekolah dasar dalam melaksanakan pembelajaran tematik-integratif sesuai dengan Kurikulum 2013, guru sekolah dasar di Kota Yogyakarta sudah siap melaksanakan pembelajaran tematik-integratif. Kesiapan guru jika dilihat dari masing-masing aspek adalah sebagai berikut: (a) kesiapan guru dari aspek Emotive-Ettitudinal di kota Yogyakarta adalah 80,75\% dengan kategori sangat siap; (b) kesiapan guru dari aspek Cognitive Readiness di Kota Yogyakarta adalah $73,78 \%$ dengan kategori siap, dan (c) kesiapan dari aspek Behavioral Readiness di Kota Yogyakarta adalah 84,55\%, dengan kategori sangat siap.

Tetapi kesiapan guru ini bukan berarti guru tidak memerlukan bantuan apapun.Pada pertanyaan dalam angket nomor 5, mengenai kebutuhan guru dalam bantuan dan pendampingan dalam melaksanakan kurikulum 2013 sebagian besar guru menjawab masih membutuhkan bantuan dan pendampingan.

\section{Daftar Pustaka}

Danim, S. (2010).Perkembangan peserta didik.Bandung: Alfabeta

Depdiknas.(2006). Strategi pembelajaran yang mengaktifkan siswa. Jakarta: Depdiknas.

. (2000). Kamus besar bahasa indonesia. Edisi Ketiga. Jakarta: Balai Pustaka.

Feldman, S.R. (2012). Discovering the life span. USA: Pearson Prentice Hall.

Fogarty, R. (1991). How to integrate the curricula. Palatine: Skylight Publising Inc.

Hoover, J.J. (1990). Curriculum adaption: a five-step process for classroom implementation. Journal of Intervention in School and Clinic Vol 25:407.

Huber \& Hutchings. (2008). Integrative Learning: Mapping The Terrain International. Journal for The Scholarship of Teaching \& Learning Vol.2 No.1.

Irianto, Y B.(2011). Kebijakan pembaruan pendidikan. Jakarta: Rajawali Pers

Kemdikbud.(2013). Kompetensi Dasar SD/MI Versi Maret 1.

Kerlinger, F.N. (2006). Asas-asas penelitian behavioral edisi ketiga.Yogyakarta: Gadjah Mada University Press.

Kon Chon Min, dkk . (2012). Teachers' Understanding and Practice towards Thematic Approach in Teaching Integrated Living Skills (ILS) in Malaysia. International Journal of Humanities and Social Science. Vol. 2 No. 23 December 2012.

Kyriacou, C. (2009). Effective teaching in school (theory and practice). United Kingdom: Nelson Thornes. 
113 Vera Yuli Erviana, Kesiapan Guru Sekolah Dasar Dalam Pelaksanaan Pembelajaran...

Djemari M. (2007). Teknik penyusunan instrumen tes dan nontes. Yogyakarta: Mitra Cendikia.

Nazir, M. (2005).Metode penelitian. Bogor: Ghalia Indonesia.

Maddox, N. et. all. (2000). Learning Readiness: An Underappreciated YetVital Dimension In Experiential Learning. Jornal of Developments in Business Simulation \& Experiential Learning.

Sisdiknas. (2012). Uji Publik Kurikulum 2013: Penyederhanaan, TematikIntegratif.http://www.kemdiknas.go.id /kemdikbud/uji-publik-kurikulum2013-1. Diakses pada tanggal 10/03/2013 pukul 09.00 WIB.

Sugiyono. (2008). Metode penelitian pendidikan: pendekatan kuantitatif, kualitatif, dan $r \& d$. Bandung: Alfabeta.

Sukandi.(2003). Belajar aktif dan terpadu. Surabaya: Duta Graha Pustaka.

Sukmadinata, N.S. (2010). Metode penelitian. Bandung: Remaja Rosdakarya.

Tim Pustaka Yustisia. (2007). Panduan lengkap KTSP. Yogyakarta: Pustaka Yustisia.

Trianto. (2010). Model pembelajaran terpadu: konsep, landasan, dan implementasinya pada kurikulum tingkat satuan pendidikan (KTSP). Jakarta: Bumi Aksara.

(2012). Model pembelajaran terpadu. Jakarta: Bumi Aksara.

Zaenal Arifin. (2010). Evaluasi pembelajaran. Bandung: PT. Remaja Rosda Karya. 